Western University

Scholarship@Western

Aboriginal Policy Research Consortium International (APRCi)

2005

\title{
Country: Being and belonging on aboriginal lands
}

Melissa Lucashenko

Follow this and additional works at: https://ir.lib.uwo.ca/aprci

Part of the Human Geography Commons, and the Sociology of Culture Commons

Citation of this paper:

Lucashenko, Melissa, "Country: Being and belonging on aboriginal lands" (2005). Aboriginal Policy Research Consortium International (APRCi). 404.

https://ir.lib.uwo.ca/aprci/404 
This article was downloaded by: [University of Western Ontario]

On: 20 December 2012, At: 11:26

Publisher: Routledge

Informa Ltd Registered in England and Wales Registered Number: 1072954 Registered office: Mortimer House, 37-41 Mortimer Street, London W1T 3J H, UK

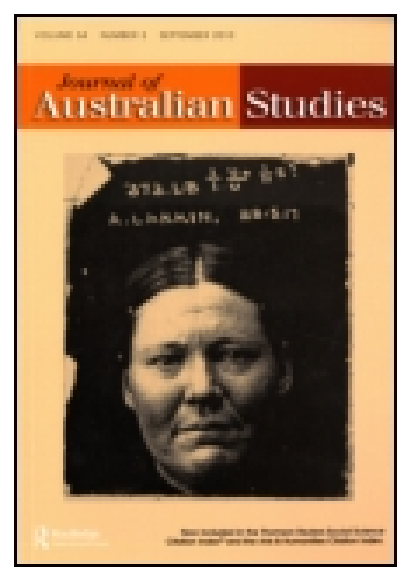

\section{J ournal of Australian Studies}

Publication details, including instructions for authors and subscription information: http:// www.tandfonline.com/loi/ rjau20

\section{Country: Being and belonging on aboriginal lands}

Melissa Lucashenko

Version of record first published: 18 May 2009.

To cite this article: Melissa Lucashenko (2005): Country: Being and belonging on aboriginal lands, J ournal of Australian Studies, 29:86, 7-12

To link to this article: http:// dx. doi.org/ 10.1080/ 14443050509388027

\section{PLEASE SCROLL DOWN FOR ARTICLE}

Full terms and conditions of use: http://www.tandfonline.com/page/terms-and-conditions

This article may be used for research, teaching, and private study purposes. Any substantial or systematic reproduction, redistribution, reselling, loan, sub-licensing, systematic supply, or distribution in any form to anyone is expressly forbidden.

The publisher does not give any warranty express or implied or make any representation that the contents will be complete or accurate or up to date. The accuracy of any instructions, formulae, and drug doses should be independently verified with primary sources. The publisher shall not be liable for any loss, actions, claims, proceedings, demand, or costs or damages whatsoever or howsoever caused arising directly or indirectly in connection with or arising out of the use of this material. 


\section{Unsettlement}




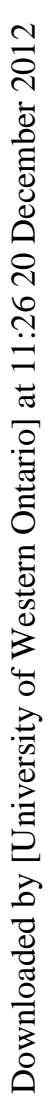




\section{Country: Being and Belonging on Aboriginal Lands}

\section{Melissa Lucashenko}

I have given myself a fair amount of trouble writing this piece. Usually, words come easily to me, and writer's block is a syndrome I'm not troubled by. But when I sat down to think about this thing called country, any fluency and ease evaporated. At first, and I am speaking of some months here, no useful words would come. The concept of 'country' seemed to me to be simple, and selfcontained. It seemed that the truths I knew about country were mere truisms, and that my imaginings of country were so simple to me, and yet so obscure to others, that there was little point in talking of them.

So I spoke with my husband. I went to learned authors, poets especially. I went and sat in the bush. I sat as I often do in my suburban backyard, looking at the trees. I tended my vegetable garden. I spoke to the magpies, and said the Ancestor names of the peewees and the black wattle that flourish near my house. I constantly asked the question: what is this thing country? What does country mean? My task was complicated by the fact that I don't currently live in country that is in any sense my own, either by blood or by long and legitimate residence. I was forced to grope for meanings while surrounded by what was literally unfamiliar.

Looking back I realise that I didn't ask many Aboriginal people what country 'meant'. To them it would have seemed a strange, almost ridiculous, question. So mostly I spoke aloud to white people. I learned as I questioned and searched that to many non-Aborigines who have understanding of Aboriginal ways, country is now synonymous with belonging. If a woman can only find the right country, I was told, she will find her Home at last. One white man told me that country meant the feelings he felt on Anzac Day-of seeing white male power structures reinforced, and being simultaneously moved and repulsed by this European ceremony. I interpreted his discomfort to mean, once more, some sort of nonbelonging here. Or a belonging to an unwanted place, an illegitimate belonging. The same man also alluded to his journey of finding his own and his family's history in the South. Of street names, suburbs, of retuming to the places of his youth and undertaking the serious and important work of finding his memory.

I spoke with others who said country meant Home, but who added the caveat that Home resided in people rather than places-a kind of portable Country. This idea, coming from Sea People, didn't fit my Earth people jigsaw at all, and I quickly put it aside. I gave attention to these things: Saltwater Country, Freshwater Country, cold and hot, high and low. Here and There. Mine, and so much notmine, strange and foreign.

And after all this talk and reading my answers were still false, disgusting to me. I wavered politically. First to one edge-this is our country, not yours in your historical murders and current shame-and then to another-we all share country, we all must live here, Aboriginal and Other alike, and the only question is how to 
do that honourably. I tried to tease out some ways in which non-Indigenous people have understood country. I made categories: Country as Economy. Country as Geography. Country as Society. Country as Myth. Country as History. Words came, but they were unsatisfactory and shallow. For all that I walked, slept, breathed and dreamed Country, the language still would not come. My trust in words had finally come to this: Nothing. I began to think I might have to deliver mere rhetoric to you, rather than something that might sustain us both.

But if the Aboriginal people of Northwest Australia are correct in their cosmology, then surely Nothing is Nothing. Not only country, but also my confusion, had a meaning worth discovering. And there was indeed a meaning, hidden and dormant. Looking back I am unsurprised. 'The land', Barry Lopez has written, 'does not give easily. The desert is like a boulder, you expect to wait'. And with time, my stupidity and ignorance faded a little. At long last I remembered to perform the difficult work of waiting.

As I waited I found this story about being and belonging to country.

Once upon a time, to coin a phrase, a family lived in the forest in a house they had built themselves. They had lived there for as long as anyone could remember. The father worked as a scientist and was mostly in the woods. The mother worked as an artist, and was mostly in the house. Although they worked alone for long hours every day, together they ate their meals and in front of a roaring log fire at night they had long conversations and in this way the two of them made sense of one world.

Of a morning the man would gather his notebooks and satchel, and walk off along tracks that he knew very well, since he himself had walked them with his father, who had also been a forest worker. Sometimes the man would come across old people of the district who had known his fathers and his grandfathers. Without fail, they would comment on his similarity to these men. He had their same straight backs, and their creased foreheads. It happened so often that he took these comments for granted. The man understood that it was important for the old people to see his forefathers in him, and he never argued against their imaginations. He was a man who had the gift of agreement in him. He allowed the greybeards to believe that he was of one mind with them, and everyone went away happy.

The woman lived in the wooden house that she had designed with her own cleverness, and which she and the man had constructed with their own labour. It had high ceilings that the woman covered with cunningly conceived objectstreasures to capture the favours of the Gods. Above her kitchen sink she nailed a fertility cradle, with a baby's shirt in it. Her ochred sculptures were on the walls of the living room, beautifully, majestically. The verandah's wooden boards were smooth and aged with the wear of many feet over many years. Her poetry covered the walls of the toilet so that mere physical necessity became at worst a diversion, and at best a journey towards light. The woman made excellent healing teas; the man would enter the house at night and know that together they had made a home fit for children. On the weekends they put their work aside and tended the garden.

People said they were a little bit crazy, but neither of them cared. They had the forest, and the house. They had plenty of visitors throughout the year, and they had 
each other. In time children came, four in all, so that to the scientist and the artist were added a farmer, a doctor, a diplomat and last, and very happily, a cook. The diplomat and the doctor chose to travel and marry outside the forest community. The cook and the farmer preferred to stay in the forest, adding their bodies, their labour and their lives to the sum of their parents. It is difficult to say whether this last pair was the happiest of the four children, but on balance I think they were.

The mother and father watched their children become big, and they were pleased to think that their children were loved and of use in the world. One day, the man, who was by now elderly, took his satchel and his notebooks into the forest. By dark he hadn't returned. The woman and the two remaining children were naturally worried, and went looking for him. They located him by his groans. The man lay in a gully; his head broken by the rock he had fallen against. There was nothing for it-they nursed him home, and sat by him for four nights. The man died on the fifth day, and they buried him beside his fathers and grandfathers in the cemetery. The old greybeards of the district came and payed their respects. He was a good man, they told his family, he knew how to behave with honour, and he remembered his people. The family sorrowed. They sent word to the diplomat and the doctor, who sent back an engraved plaque of remembrance, and a tree to plant over the father's grave. The mother took care of this business, and life went on.

One morning, a long time after, as the mother was comforting a grandchild upon her knee, she heard a sharp sound in the forest that she had never heard before. She exchanged glances with the farmer, who was at the breakfast table. The farmer rose to see what was going on. When he opened the door, strangers stood before him. The discussion of that morning turned quickly to the disagreement of that afternoon. The strangers were ignorant people with no agreement in them. All they knew was their own ways, and their own needs.

We shouldn't be so surprised that the strangers brutally killed the farmer and threw his body in the scrub. They murdered the mother without calling it murder. They would have killed the cook, but she was collecting firewood and had a feeling she shouldn't go home just then. The child also died. The strangers looked at the wooden house and found it ugly; they burned it to the ground. The woman's poetry was read aloud and ridiculed, then tossed on the rubbish heap. Her beautiful fertility cradle caught their eye, and was kept as a plaything. Then the strangers brought in their own art, their own houses, their own children. They lived on the ancestral grounds, and ploughed the people's cemetery to grow their crops.

The following year the doctor came home wondering why he hadn't heard from anyone for such a long time. As he approached the house he unknowingly stumbled against his brother's skull, which lay half-buried in the soil outside. When the doctor looked up from his stumble, he saw to his great surprise that the house had changed beyond recognition. He knocked on the new door, and it was opened by strangers who smiled uncomprehendingly at him. The doctor looked into the new house. The body of his mother lay dusty and unmourned in a comer of the main room. He shrieked with rage and sorrow, asking them why his mother was a corpse, where were his brothers and sister, what on earth had happened in this wretched place? 
'What corpse?' the strangers said in puzzlement. The doctor ran to his mother's remains, and kneeled by them, sobbing. But no matter how hard the doctor tried, he couldn't make them see his mother's body lying in their new house.

'What brothers and sister?' the strangers said. 'It is our family who lives here. Your family must have gone away for some reason of their own'.

'Why do you call it wretched?' they said. 'This is a wonderful place with fertile soils and people just like us who live happily together'.

At this the doctor let out a great wail of anguish, knowing that he could never make the strangers give back his mother, his family, his home. He wailed and wailed.

'Don't cry so', said some of the strangers in concern. 'Why don't you live here with us, and together we can make a new home'. Then the doctor stopped his wailing and fixed them with a glance like a knife.

'You are thieves and murderers and liars in my father's country', he said, 'and I curse you and all your children till the end of time'. As he moved to pick up his mother's body the doctor was seized, overpowered and made ready for imprisonment. As they made to take him away, one woman approached him with a sorrowful look.

'Why do you speak to us in this way?' asked the woman of the strangers' clan. Tears welled in her eyes and she wrung her hands. "Why do you have such hard words when this is our home and we are now the people of this place and we belong here?'

And the doctor had no answer that she had ears to hear. 